\section{Mapping of capacities for research on health and its social determinants in Brazil}

\author{
Mapeamento da produção e das estruturas de \\ pesquisa sobre determinantes sociais da \\ saúde no Brasil
}

\section{Mapeo de capacidades para la investigación sobre determinantes sociales de la salud en Brasil}

\begin{abstract}
This article describes tendencies in research on social determinants of health (SDH) and health inequities in Brazil (2005-2012) and maps research system structures to analyze capacities for research on health and its social determinants. Brazil has a strong national research system and counts on a wealth of research in the field of SDH drawing on a long tradition of research and political commitment in this area. While innovative strategies seeking to strengthen the links between research, policy and practice have been developed, the impact of SDH research continues to be largely restricted to the academic community with notable but still insufficient repercussions on public policy and the social determinants of health inequities. SDH research in Brazil will therefore need to become even more responsive to social urgencies and better attuned to political processes, enhancing its capacity to influence strategic policy decisions affecting health inequities and mobilize strategic agendas for health equity.
\end{abstract}

Health Inequalities; Health Research Policy; Social Determinants of Health
Elis Borde 1

Marco Akerman 2

Alberto Pellegrini Filho ${ }^{1}$

\section{Resumo}

Este artigo descreve as tendências na produção de pesquisa sobre os determinantes sociais da saúde (DSS) no Brasil (2005-2012) e mapeia as estruturas do sistema de pesquisa sobre saúde e seus determinantes sociais. O país tem um sólido sistema nacional de pesquisa e conta com uma rica produção sobre DSS e suas iniquidades ancoradas em uma longa tradição de pesquisa e compromisso político nesse campo. Apesar das estratégias inovadoras que buscam fortalecer os vínculos entre pesquisa, políticas e práticas, o impacto da investigação sobre DSS continua a ser em grande parte restrito à comunidade acadêmica, com repercussões notáveis, mas ainda insuficientes sobre a política pública e os determinantes sociais das iniquidades em saúde. Portanto, a pesquisa sobre DSS no Brasil necessita tornar-se ainda mais sensível às urgências sociais e desenvolver uma melhor sintonia com os processos políticos, aumentando a sua capacidade de influenciar decisões estratégicas que possam afetar as iniquidades em saúde e mobilizar agendas para a promoção da equidade.

Desigualdades em Saúde; Política de Pesquisa em Saúde; Determinantes Sociais da Saúde 


\section{Introduction}

Brazil presents both major inequalities in the distribution of wealth as well as considerable levels of poverty, which has shaped health inequalities 1 . In this regard, the 2008 report from the Brazilian National Commission on Social Determinants of Health (CNDSS) 1 refers to, amongst other things, the notable social gradient in the use of and access to health services and the socioeconomic, ethnic/racial and regional inequalities in infant mortality, micronutrient deficiency, acute respiratory infections and diarrheas, to name just a few examples.

Developments such as the democratization process after the military dictatorship from 1964 until the late 1980s, advances in education, and the strong reform movement that led to the inclusion of the right to health in the Brazilian Constitution of 1988 and the creation of the Brazilian Unified National Health System (SUS), have undoubtedly facilitated advances in several areas of public health 1,2 . In this regard, important improvements in health status and life expectancy have been ascribed to progress achieved through action on social determinants of health and to the implementation of a comprehensive national health system with strong levels of social participation 2 .

Even in light of these promising trends, child mortality rates in the north of Brazil remain twice as high as rates in the south, inequalities between ethnic/racial groups persist with regard to maternal/child health, chronic diseases and levels of violence, and despite the principles of universality and equity that govern the SUS, access to health care remains unequal across social strata 1,2 .

While it is often assumed that ill-health and death could be avoided by "simply" applying existing knowledge ${ }^{3}$, the complexity of certain health problems, including socially determined and historically rooted health inequities, demands more research with greater contextual relevance. This involves the identification of more efficient and effective ways to protect and promote health and, specifically with regard to social inequities in health, must involve analyses that account for the complex interactions between social inequities and health and further evidence the contexts and patterns of exclusion, oppression and conflict that shape these inequities in Brazil and elsewhere. Difficulties further arise from deficient national health research systems and inadequate research communication mechanisms that hamper the articulation between research, policy and practice for social justice and health equity. While research on social inequali- ties in health has a long tradition in Brazil, mostly tied to the Latin American Social Medicine and Public Health movement 4 , the scope and impact of social determinants of health (SDH) and health inequity research continues to be largely restricted to the academic community with notable but still insufficient repercussions on public policy and the social determinants of health inequities in Brazil - an issue discussed, for example, by Pellegrini Filho ${ }^{5}$.

This article seeks to contribute to the identification of capacities for research on health and its social determinants in Brazil by mapping research activities and the scope of SDH research as well as research system structures, policies and networks defining research on health and its social determinants in Brazil, focusing on the developments since the establishment of the World Health Organization Commission on SDH $(\mathrm{CSDH})$ in 2005. The information presented in this article is based on a mapping exercise, which formed part of the first phase of the European Union funded collaborative action SDH-Net (http://www.sdh-net.eu/) and sought to inform SDH-Net's phase 2 research capacity building measures and identify entry points for action.

\section{Methods}

The mapping was completed on the basis of (a) literature reviews, (b) semi-structured key-informant interviews and (c) database consultations (Research Group Directory of the Lattes Platform and Virtual Health Library - VHL), which were performed by the authors between May and July 2012.

The four key-informants were selected on the basis of their curriculum vitae, their experience in the field of SDH/health inequity research and policy and the position they are currently holding. Half of the semi-structured interviews were carried out in the experts' workplaces by one of the authors (E.B.), while the remainder were conducted by means of email interview. The interviews were analysed using qualitative content analysis.

The database consultations were limited to the Research Group Directory of the Lattes Platform and the VHL. The latter is designed to provide equitable access to scientific knowledge on health and includes those public health journals that concentrate research production on $\mathrm{SDH}$ in Brazil. Both the research group directory of the Lattes platform by the Brazilian National Research Council (CNPq) and the VHL were searched in June 2012, using four specific "exact phrase" search terms and "Brazil": (a) "determi- 
nantes sociais da saúde" (English equivalent: social determinants of health), (b) "desigualdades sociais em saúde" (English equivalent: social health inequalities) and the Health Science Descriptors (DeCS) search terms (c) "desigualdades em saúde" (English equivalent: inequalities in health) and (d) "equidade em saúde" (English equivalent: equity in health). The articles identified in the VHL were organized according to (a) health reference, (b) inequality/inequity reference, (c) type of research, (d) target group and (e) language of publication.

It should be noted that the database consultations have several limitations and seem to underestimate the number of publications and research groups identified. The results of the mapping exercise, which are discussed in this article, should therefore be interpreted with caution and trends rather than specific numbers should be deduced from this article.

\section{Knowledge production and dissemination}

\section{SDH on the national (research) agenda}

Similar to other Latin American countries, Brazil has a long-standing tradition in the field of research on health inequalities 4 . This is mostly tied to the Latin American Social Medicine and Public Health movement which has found its expression, among others, in the Asociación Latinoamericana de Medicina Social (ALAMES). In Brazil, the movement developed amongst others through the Brazilian Center for Health Research (CEBES) and the Brazilian Association of Public Health (ABRASCO), which were strongly involved in the Brazilian Sanitary Movement of the 1970s and 1980s, and culminated in the recognition of health as a right in the Brazilian Constitution of 1988 and the subsequent development of the SUS. In this regard, the political struggles for universal, integral and decentralized health care, in which public/collective health researchers were heavily involved, have undoubtedly shaped research on SDH and health inequities in Brazil.

As a result of its history and experience in this area, in Brazil, SDH are widely recognized. Brazil has established systems (e.g. the SUS) and has set up political-organizational structures (e.g. Health Councils) that are rooted in the Brazilian Sanitary Movement and present in the National Constitution, which give continuity and stability to the efforts directed at SDH and health inequities. In fact, Brazil was one of the first countries to create a national commission on SDH, in 2006. The creation of the CSDH in 2005 helped renew interest in social determinants of health and gave new impetus to a long tradition of research and action on SDH and health inequities in Brazil 6.

Furthermore, the early official involvement of Brazil has been related to a tradition of commitment to unequal health conditions 7, which previously contributed to the recognition of health as a right of citizens and a duty of the state in the National Constitution of 1988 .

Responding to a resolution by the member states of the World Health Assembly, where the need for a global event to address health inequities and social determinants of health was articulated, the Brazilian Ministry of Health, in collaboration with the Oswaldo Cruz Foundation (Fiocruz) and the Wolrd Health Organization (WHO), hosted the World Conference on SDH (WCSDH) in October 2011. The event took place in Rio de Janeiro and primarily focused on strategies for action on SDH 7. Considering the country's long tradition of research and action on SDH and health inequities, it is no coincidence that the WCSDH took place in Brazil. In fact, the WCSDH in Rio de Janeiro can be seen as an expression of Brazil's leadership role in the global movement on SDH and also as an attempt to renew the debate on SDH at the national level.

While the WCSDH marked yet another step in the global mobilization around SDH that followed the establishment of the CSDH, substantial theoretical and political differences in the debate around SDH, which were invisible up until that point, became evident in the context of the WCSDH and with the publication of the Rio Political Declaration. In this regard, three alternative declarations were issued by the Peoples Health Movement (PHM), the ALAMES and the CEBES as well as the International Federation of Medical Students (IFMSA), respectively, manifesting differences with respect to the official WHO Declaration, which have been summarized in two books 9,10 and a special issue 11 in a leading Brazilian health journal. The authors refer to differences in concerns about the way social health inequities are being related to forms of social organization and to the asymmetries of power characterizing contemporary capitalist societies. While the CSDH is unanimously recognized as an important milestone in the mobilization against health inequities, it is argued that the SDH approach, promoted by the CSDH, does not sufficiently challenge the inherently unjust and health threatening system and proposes important yet insufficient redistributive policies to alleviate social inequities, while not considering the processes by which the social inequities are produced and reinforced, that is, the patterns of exclusion, oppression and conflict that shape 
social inequities and health inequities in Brazil and elsewhere. Furthermore, concerns are being raised regarding the way knowledge is produced in (epidemiological) studies incorporating the WHO SDH approach, pointing at conceptual and methodological limitations specifically regarding the use of analytical categories like gender, ethnicity/race and social class, but also what regards notions of risk and causality, which are considered insufficient to capture the complexity inherent in the configuration of social inequities in health.

These developments have undoubtedly had repercussions on knowledge production on SDH and health inequities in Brazil, resulting, for example, in a special issue on the debate in the same Brazilian public health journal 11. The debates further seem to have contributed to a growing consciousness among Brazilian SDH researchers regarding ontological and epistemological differences in SDH research, which may contribute to overcome the often lamented and serious theoretical shortcomings of mainstream $\mathrm{SDH}$ research as discussed by Kelly et al. 12, Breilh ${ }^{13}$, Almeida-Filho 14 and others.

\section{Dissemination of SDH research}

Brazil is the largest producer and health information user in Latin America and the Caribbean 15 and is responsible for a large share of the significant increases in publications on health inequalities 16,17. Research on SDH is broadly disseminated in Brazil and unlike in other countries, specific institutions and portals have been set up in order to support knowledge transfer processes, position SDH on strategic agendas and monitor health inequities.

A descriptive study on the Brazilian research environment from 2009 suggests that access to scientific information, as well as opportunities for publishing research results, are satisfactory in Brazil 18. Scientific journals continue to be the principle vehicle for research communication in Brazil. In this regard, we found that publications on SDH and health inequities are concentrated in two main academic journals whose articles are accepted in English, Spanish and Portuguese and follow the open-access policy: Cadernos de Saúde Pública, published monthly by the National School of Public Health (ENSP/ Fiocruz) and Revista de Saúde Pública, published bimonthly by the Faculty of Public Health of the University of São Paulo (USP) ${ }^{19}$. SDH research is further published in the journals Saúde em Debate and Ciência e Saúde Coletiva, which gained recognition and international prominence. Our database consultations suggest that articles on
SDH and health inequities relating to Brazil are predominantly published in Portuguese, which is further discussed below. This publication pattern has facilitated dialogue and uptake of research results at the national level. On the downside, this has limited international visibility of Brazilian research on SDH and worldwide academic exchange.

While several Latin American and Brazilian journals are indexed by MEDLINE, the Latin American Literature in Health Sciences (LILACS) database and the VHL referred to above (both of which are maintained by the Latin American and Caribbean Center on Health Sciences - BIREME) index the majority of Latin American, including Brazilian, journals. Evidence on SDH is further pooled in the Virtual Health Library on Social Determinants of Health (BVS DSS) (http://bvsdss. icict.fiocruz.br), which has facilitated access to evidence on SDH. Maintained by the Center for Studies, Policies and Information on Social Determinants of Health (CEPI-DSS) of the ENSP/ Fiocruz, this constitutes an important research information management system in the field of SDH.

Furthermore, SDH related evidence, including research results, interviews, expert opinions and experiences, is pooled in the online Portal on SDH (http://dssbr.org/site, accessed on 27/ Aug/2013). The Portal further hosts the Brazilian Health Inequities Observatory, developed in 2011 by the CEPI-DSS of ENSP/Fiocruz to monitor tendencies in health inequities in Brazil from 2000 on the basis of 60 indicators, largely corresponding to the recommendations of the $\mathrm{WHO}$ CSDH. The Observatory's aim is to analyse the impact of policies and programs on health inequities, promote research in this area, contribute to the improvement of health information systems in general and increase the visibility of health inequities on national and international agendas (http://dssbr.org/site, accessed on 27/ Aug/2013).

Since January 2013, interviews, news, articles and experiences on health and its social determinants related to the Brazilian Northeast are further pooled on the Northeast SDH Portal (http:// dssbr.org/site/nordeste/) linked to the SDH Portal mentioned above. In an effort to move beyond virtual exchange and provide a forum for exchange between researchers, policy makers and members of civil society, a Regional Conference on Social Determinants of Health was held from September 2-4 in Recife (Brazil) and constituted the first conference in a series of conferences on SDH foreseen in other regions of Brazil. The conference sought to analyse the regional health situation focusing on SDH, revising policies and 
programs that have been implemented in the region to combat the persisting social inequities in health. Despite these promising initiatives, difficulties in the production and use of scientific evidence that supports the definition, implementation and evaluation of policies to combat health inequities through action on social determinants of health persist, as Pellegrini Filho ${ }^{5}$ points out.

\section{Research infrastructure}

\section{Research system structure}

In Brazil, the main health research actors at federal government level are the Ministry of Health through the Department of Science and Technology (DECIT); the Ministry of Science and Technology through the CNPq and the Financial Agency for Studies and Projects (FINEP); the Ministry of Education through the Graduate Studies Coordinating Board (CAPES); the Health Sector Fund; and Research Support Agencies (FAPs) from the 27 Brazilian states.

Health research governance and management is led by the Ministry of Health and guided by the National Policy on Health Science, Technology and Innovation (PNCTIS), as well as the National Health Research Priority Agenda (ANPPS). The Brazilian research system is organized as outlined in Figure 1, taken from Access4. eu (http://www.access4.eu/brazil/330.php).

\section{Research priority setting}

Evidence suggests that research in collective health is increasingly focusing on topics that are highly relevant for the Brazilian context, directly contributing to the improvement of the SUS and reflecting pressing public health issues 20 . This development is linked to a growing consciousness of the strategic role of nationally relevant research results in promoting health and overcoming health inequities, but has specifically resulted from the health research priority setting process in Brazil. This significantly contributed to synergies between research needs and research activity, because the priority setting process resulted in specific calls for proposals that covered the previously identified health research priorities 21 . The Brazilian research community and public health groups traditionally have a strong role in influencing the definition and implantation of scientific policies. Rather than the government or international agencies setting the research agenda and scientists following it, there has accordingly been a good collaboration between the different actors and commitments have been shared. Ex- amples include the above mentioned definition of health research priorities, under the leadership of the Ministry of Health, and wide participation of research groups and civil society. The evaluation of postgraduate courses by scientific committees organized by CAPES as well as the review committees of $\mathrm{CNPq}$ for the assignment of research grants constitute other examples.

While SDH and health inequities do not appear as specific items on the National Agenda of Priorities in Health Research (NAPHR), they are implied in most research priorities and are accordingly understood as transversal elements of all health research issues.

Following the priority setting process, the Ministry of Health and partners allocated around US\$ 419 million to support almost 3,600 projects along with 135 public calls for proposals, of which the highest proportion was directed at the sub-agendas "industrial health complex", "clinical research" and "communicable diseases" 22. Commenting on how the Brazilian Ministry of Health's research support policy fulfilled the NAPHR, Pacheco Santos et al. 22 conclude that the effort in guiding the health research policy has been achieved. The authors highly value the Brazilian experience, showing that the funding allocation was in accordance with economic and regional health characteristics and needs. They further argue that the affirmative policy to combat regional inequities in health research was successful and refer to the number of approved projects, which was highest in the Northeastern region. It must, however, be mentioned that the greatest sum of investment was allocated to the Southeast.

\section{Funding}

Since 2004, health research financing has been geared towards the NAPHR and has considerably increased 2 , which has undoubtedly contributed to the intensification of research activity, also around SDH and health inequity, in Brazil. According to Santos et al. 23, DECIT financed 3,700 projects with a total budget of US $\$ 400$ million (more than BRL 907 million at 2009 exchange rates) from 2003 to 2009.

$\mathrm{SDH}$ and health inequity research is predominantly financed through public resources in Brazil. In the context of the CNDSS, a specific SDH research funding line was established with a total value of almost US\$ 2 million, representing around $1.12 \%$ of the overall health research budget. As $\mathrm{SDH} /$ health inequity research has been further funded through other research funding programs, the percentage of funds directed to $\mathrm{SDH} /$ health inequity research is most 

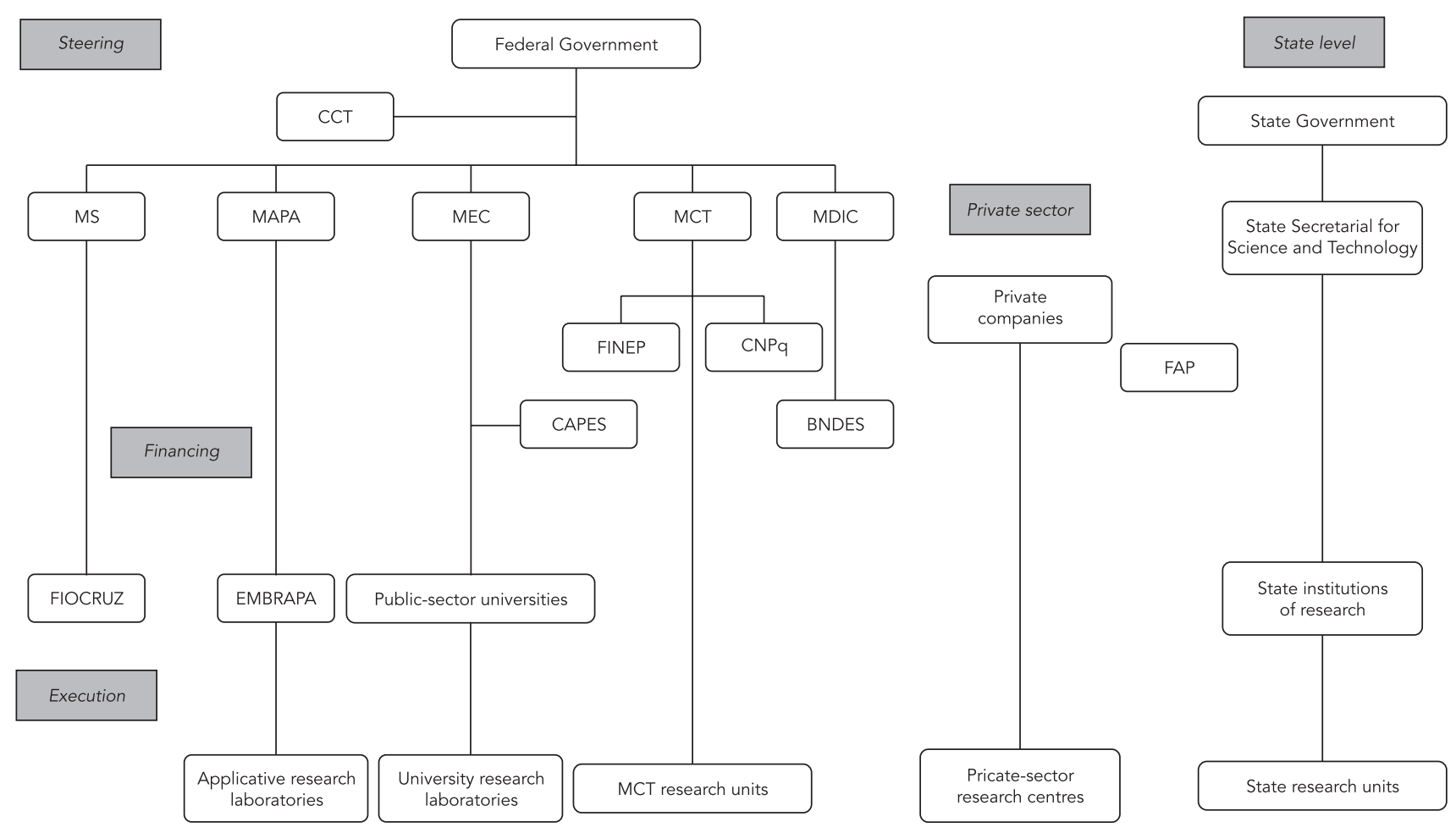

Source: ACCESS4.EU (http://www.access4.eu/brazil/330.php).

certainly higher than $1.12 \%$. In this regard, several key informants suggested that funding for health research is more accessible than ever, with increased resources and more transparent funding mechanisms. It is, however, not clear whether this applies to SDH research and whether all branches of SDH research have equally good access to public funding. Qualitative research, for example, is traditionally under-funded and the results of this mapping exercise do not provide any evidence for a contrary trend in Brazil.

\section{Research capacity}

\section{Quantity of research}

An analysis of research on health inequalities 4 suggests that Brazil accounts for more than $50 \%$ of the overall research output of the region, which according to the authors reflects institutional support mechanisms and is not simply a result of the relative population size. This is confirmed by Victora et al. 2 who attributes the increase in publications in peer-reviewed scientific journals from 14,237 in 2003 to 30,415 in 2008 to substantial increases in government investment in research, particularly in the form of grants and performance-based funding for researchers and academic departments. Furthermore, Aquino 24 ascribes the increase of epidemiological research to the growing numbers of postgraduate programs and students in Brazil. While these absolute increases certainly indicate greater research activity, the observed tendencies must also be considered in relative terms, that is, in relation to the overall increase of scientific publications worldwide 25 . In this sense, the increase is significant but less marked. Our database consultations indicate peaks in publications on $\mathrm{SDH}$ and health inequities in the years 2007 and 2010, which may, but does not necessarily, reflect the work of the WHO CSDH and the CNDSS in putting $\mathrm{SDH}$ and health inequities on to research 
agendas and raising awareness among researchers and policy makers.

A total of 69 research groups with at least one line of research directly related to the search terms were identified in the research group directory of the Lattes platform. The regional distribution reveals significant differences, with a majority in the Southeastern region (52\%) and, at the other extreme, none at all in the Northern region. Research groups in the Southeast are concentrated, most prominently, at Fiocruz and the USP. Notable exceptions to the regional concentration are the Federal University of Bahia (UFBA) and the Federal University of Pernambuco (UFPE), located in Northeastern Brazil, with four and three SDH research groups, respectively.

After controlling for duplications, the VHL consultation rendered a total of 222 articles, covering the years 2005 to 2012, which were organized according to (a) health reference, (b) inequality/inequity reference, (c) type of research, (d) target group and (e) language of publication.

The great majority of the articles were indexed under the search term "health inequalities". With respect to the language of publication, the review showed that articles on SDH and health inequities relating to Brazil were predominantly published in Portuguese. Only $12.6 \%$ were published in English. A simple web search identified several relevant $\mathrm{SDH} /$ health inequity publications that could not be identified on the VHL. This highlights the limitations of the search strategy, as it seems to underestimate the number of publications and research groups identified, which can partly be attributed to the lack of a DECS term for SDH. In this regard, many researchers do not necessarily use the term "social determinants of health" or any of the other terms we used as key words, but rather refer to specific (public) health conditions.

\section{Number of researchers}

CNPq census data from 2004 recorded 20,000 research groups and more than 75,000 active researchers in Brazil 26. In 2004, 6471 research groups were involved in health research in Brazil, with 25,562 researchers, 15,978 of whom had a PhD 21. On May 25th, 2012, the Lattes platform listed a total of 1,828 researchers, with at least a $\mathrm{PhD}$ degree, involved in research around "social determinants of health", 1,142 in "equity in health", 2,650 in "social determination in health", 1,844 in "social inequality in health", and a total of 1,495 researchers involved in research around "social inequalities in health". These numbers point to substantial interest in SDH, health inequities and related fields. Taking the numbers discussed by Guimarães 26 from 2004 as a basis for an approximate calculation, approximately $7 \%$ of all health researchers in Brazil are involved in SDH/health inequity research. Thus, it can be assumed that Brazil counts on a critical mass of $\mathrm{SDH} /$ health inequity researchers.

\section{Type of research}

While most research groups were listed under the general research field "Public Health" (51, corresponding to $74 \%), 18$ (26\%) were listed under other fields, specifically Dentistry, with a total of nine research groups carrying out research on $\mathrm{SDH}$ and health inequities and the remaining nine research groups listed under Sociology and Nutrition. Interestingly, just one of the research groups was listed under the field of Medicine, which proves that unlike other countries, Public Health is a well-established field of research and action in Brazil that is largely independent from medicine.

In general, a diversification of research lines is being observed in the field of public health in Brazil 27,28 , which also seems to apply to SDH and health inequity research. Barreto 27 notes that a diversification resulting from the growing involvement of researchers from other disciplines contributes to the field's richness, but warns of possible fragmentation.

In this regard, our results suggest that there is a shift away from mostly conceptual and theoretical studies, that marked the field until the late 1990s 4 towards more empirical, epidemiological studies that currently dominate $\mathrm{SDH}$ research in Brazil. SDH were accordingly predominantly addressed using approaches based on the socioeconomic and historical context, putting emphasis on the political processes involved in the production (working conditions) and reproduction (class structure) processes of society 17 , which implies a focus on the "social determination processes" rather than on "social determinants", which have been criticized for reducing the complexity of disease emergence and persistence and fragmenting the study objective and, accordingly, also the possibilities for action 11,29. Although the influence of the Latin American Social Medicine and Public Health movement is still evident in the current debates and research production on SDH in Brazil, these approaches no longer seem to define the debates and research agendas, which may owe much to the influence of key researchers returning to Brazil after having earned their PhDs at European and North American universities. The results of the bibliometric and descriptive content analysis by Almeida-Filho et al. 4 further point 
to the fact that the intensification of research activity in Brazil came along with a diversification of the field as many more researchers and research groups started undertaking research. The results further indicate that many studies on health inequalities in Brazil were conducted with research grants linked to programs committed to the definition of public policies (in the 1980s the FINEP public health program, DECIT agenda and others) which demanded empirical research geared towards the resolution of concrete health problems.

In terms of ontological and epistemological differences in SDH research outlined above, Brazilian SDH research in this regard seems to reflect a convergence of research traditions (Latin American Social Medicine and the Public Health movement and the Anglo-Saxon tradition of SDH research), although increasingly privileging ontological, epistemological and praxiological principles that are characteristic of the Anglo-Saxon tradition of SDH research 8 .

Most articles listed under the above mentioned search terms referred to reviews (40\%) and quantitative studies (36.5\%), while qualitative methods were less commonly reported (14\%).

\section{Training}

50 in every one million people graduate from university every year with a $\mathrm{PhD}$ degree in Brazil, which is a relatively high number when compared to other Latin American countries, such as Colombia, where this proportion is only 1.8 per million 30. CAPES (http://www.capes.gov.br/ cursos-recomendados) lists a total of 68 postgraduate programs in the field of Public Health, which are tri-annually evaluated using a scale from 1 to 7 (best possible evaluation). The accreditation of programs with an evaluation below 3 is withdrawn. In the field of Public Health, 16 postgraduate programs (Masters and $\mathrm{PhDs}$ ) received the a grade of 6 or 7 . The considerable number of postgraduate programs in the field of Public Health, the newly set up undergraduate programs and the satisfactory evaluations in the field suggest that training opportunities (indirectly) related to $\mathrm{SDH}$ and health inequities are ample and the current training conditions are likely to sustain the above referred critical mass of collective health researchers in Brazil 3.

\section{Conclusions}

Politically, Brazil has assumed international leadership in the mobilization around SDH and has gained major visibility as reflected by its hosting of major international conferences on this topic the creation of a CNDSS and the early involvement in the WHO CSDH.

However, despite Brazil's leadership on SDH and positive developments regarding SDH research and dissemination, there are still challenges. The Brazilian health information systems, for example, continue to report health indicators in average numbers, masking major health disparities, particularly the social, ethnic/racial, and regional inequities that continue to plague Brazilian society and define health inequities ${ }^{2}$. Following Guimarães et al. ${ }^{31}$, the Brazilian national health research system, furthermore, continues to face bureaucratic difficulties that hinder the efficient transfer of resources from government level to researchers and research institutes, which may also have repercussions on the availability of resources for SDH research.

On the positive side, government changes in Brazil are rather unlikely to reverse efforts on $\mathrm{SDH}$, as several efforts have been integrated in institutional structures and the right to health is anchored in the Brazilian Constitution.

The results of this mapping exercise suggest that articles on SDH and health inequities are mostly published in Portuguese, which has probably been key to the intensive (research) interest and political commitment to SDH and health inequities in Brazil, but at the same time, has restrained international visibility of Brazilian SDH research, at least outside Latin America. It should be noted that the language of publication is obviously not the only factor defining the international visibility of research, but that important research contributions have systematically been made invisible at international level. Examples include the disregard of the notable contributions of the Latin American Social Medicine and Public Health Movement, to which Brazilian research has made important contributions, in WHO led SDH debates 32 .

Other challenges in Brazil include shortcomings in research communication, research evaluation and the research process as such. Despite several interesting initiatives, research results are only disseminated long after being obtained and usually only reach the scientific audience. Although notable strides have been made, SDH research results continue to have limited repercussions on policy making and health (inequity) indictors. The above referred Regional Conference on SDH in Recife (http://dssbr.org/site/2013/09/ confira-a-cobertura-da-1a-crdss-pelo-portaldss-brasil/, accessed on 27/Aug/2013) constituted an effort to reverse this trend by bringing researchers, policy makers and members of civil society together to define contextually relevant 
strategies to achieve health equity in the Brazilian Northeast.

Increases in the number of health publications in general have been related to government investment in research, particularly in the form of grants and performance-based funding for researchers and academic departments 2, which may also explain the growth in SDH/health inequity publications. While this suggests that government strategies seeking to enhance research production on the basis of performance-based funding for researchers and academic departments have been successful, it still remains uncertain as to how far these quantitative gains have been accompanied by qualitative gains in health research.

\section{Resumen}

Este artículo pretende analizar las capacidades de investigación sobre determinantes sociales de la salud (DSS) en Brasil, mapeando instituciones y grupos de investigación, así como las principales tendencias temáticas y dimensiones cuantitativas de la producción científica brasileña en este área (2005-2012). Brasil posee un sistema nacional de investigación en salud bien consolidado y la producción científica sobre la temática es amplia. Se han logrado ampliar los nexos entre la producción científica y la política pública en el campo de los DSS, estableciendo un compromiso político estable en torno a este tema. Sin embargo, cabe notar que la investigación sobre DSS continua teniendo poco impacto sobre políticas públicas y los determinantes sociales de las inequidades en salud. La investigación sobre DSS en Brasil, por lo tanto, necesita ser más sensible a las urgencias sociales y adaptarse mejor a los procesos políticos, aumentando su capacidad influencia en las decisiones políticas que afectan las inequidades en salud, además de movilizar agendas estratégicas para la equidad en salud.

Desigualdades en la Salud; Política de Investigación en Salud; Determinantes Sociales de la Salud
It should be noted that these challenges are not restricted to the field of SDH and health inequity research, but to health research in general. In this regard, several authors have called for alternative research approaches and forms of knowledge construction that extend the dialogue, reveal the uncertainties and broaden the validity assessment criteria to take better account of the complexities inherent in health problems, particularly health inequities $33,34,35$. This requires the due recognition of non-dominant research traditions, and non-scientific actors in the process of knowledge construction as well as the reassessment of research needs.

\section{Contributors}

E. Borde participated in the project design, writing of the article, critical review of the relevant literature and revision of intellectual content, data analysis and interpretation, and approval of the final version for publication. M. Akerman participated in the project design, writing of the article, interpretation of results and approval of the final version for publication. A. Pellegrini Filho participated in the project design, writing of the article, data analysis and interpretation, and approval of the final version for publication.

\section{Acknowlegments}

We gratefully acknowledge the contributions of Wendy Wisbaum and Geiza Ferreira Soares for editing this article. Furthermore, we would like to thank the key informants as well as the CSP editors and reviewers for their valuable input. The Social Determinants of Health Network (SDH-Net) is a four year (2011-2015) collaboration project, financed by the European Commission under the 7 th Framework Program for Research and was launched in October 2011. 


\section{References}

1. Comissão Nacional sobre Determinantes Sociais da Saúde. As causas sociais das iniquidades em saúde no Brasil. Rio de Janeiro: Editora Fiocruz; 2008.

2. Victora CG, Barreto ML, do Carmo Leal M, Monteiro CA, Schmidt MI, Paim J, et al. Health conditions and health-policy innovations in Brazil: the way forward. Lancet 2011; 377:2042-53.

3. Departamento de Ciência e Tecnologia, Secretaria de Ciência, Tecnologia e Insumos Estratégicos, Ministério da Saúde. Por que pesquisa em saúde? Brasília: Ministério da Saúde; 2007. (Série B. Textos Básicos de Saúde) (Série Pesquisa para Saúde: Textos para Tomada de Decisão).

4. Almeida-Filho N, Kawachi I, Pellegrini Filho A, Dachs JN. Research on health inequalities in Latin America and the Caribbean: bibliometric analysis (1971-2000) and descriptive content analysis (1971-1995). Am J Public Health 2003; 93:2037-43.

5. Pellegrini Filho A. Public policy and the social determinants of health: the challenge of the production and use of scientific evidence. Cad Saúde Pública 2011; 27 Suppl 2:S135-40.

6. Akerman M, Maymone CC, Gonçalves CB, Chioro A, Buss P. Las nuevas agendas de la salud a partir de sus determinantes sociales. In: Galvão LA, Finkelman J, Henao S, editores. Determinantes ambientales y sociales de la salud. Washington DC: Organización Panamericana de la Salud/México DF: McGraw-Hill Interamericana; 2010. p. 1-15.

7. Pellegrini Filho A, Vettore MV. Estudos brasileiros sobre determinantes sociais das iniquidades em saúde. Cad Saúde Pública 2011; 27 Suppl 2:S132-3.

8. Temporão JG. The Brazilian Commission on Social Determinants of Health: next steps. Glob Health Promot 2009; Suppl 1:45-7.

9. Hartman CE, González ST, Guzmán RG, editores. ¿Determinación social o determinantes sociales de la salud? México DF: Universidad Autónoma Metropolitana; 2011.

10. Nogueira RP, organizador. Determinação social da saúde e reforma sanitária. Rio de Janeiro: Centro Brasileiro de Estudos de Saúde; 2010.

11. Determinação social da saúde. Saúde Debate 2009; 33:341-498.

12. Kelly MP, Morgan A, Bonnefoy J, Butt J, Bergman V. The social determinants of health: developing an evidence base for political action. Final report to World Health Organization Commission on the Social Determinants of Health from Measurement and Evidence Knowledge Network. http://www. who.int/social_determinants/resources/mekn report_10oct07.pdf (accessed on 27/Aug/2013).

13. Breilh J. Una perspectiva emancipadora de la investigación e incidencia basada en la determinación social de la salud. http:/ / www.saludcolectivaunr.com.ar/docs/SeminarioBreilh03.pdf (accessed on 27/Aug/2013).

14. Almeida-Filho N. La ciencia tímida. Ensayos de deconstrucción de la epidemiología. Buenos Aires: Lugar Editorial; 2000.
15. Latin-American and Caribbean Center on Health Sciences Information, Pan American Health Organization. Evaluation report of 10 year operation of the VHL. São Paulo: Latin-American and Caribbean Center on Health Sciences Information, Pan American Health Organization; 2008.

16. Almeida-Filho N. Desigualdades em saúde segundo condições de vida: análise da produção científica na América Latina e Caribe e bibliografia anotada. Washington DC: Organização Pan-Americana da Saúde/Organização Mundial da Saúde; 1999.

17. Almeida-Filho, N. A problemática teórica da determinação social da saúde (nota breve sobre desigualdades em saúde como objeto de conhecimento). Saúde Debate 2010; 33:349-70.

18. Noronha J, Silva T, Szklo F, Barrada Barata R. Análise do sistema de pesquisa em saúde do Brasil: o ambiente de pesquisa. Saúde Soc 2009; 18:424-36.

19. Pellegrini Filho A. Science for health: notes on the organization of scientific activity for the development of health in Latin America and the Caribbean. Rev Panam Salud Pública 2000; 7:345-9.

20. A pesquisa em epidemiologia. Rev Bras Epidemiol 2005; 8 Suppl 1:18-27.

21. Guimarães R, Santos LMP, Angulo-Tuesta A, Serruya SJ. Defining and implementing a National Policy for Science, Technology, and Innovation in Health: lessons from the Brazilian experience. Cad Saúde Pública 2006; 22:1775-94.

22. Pacheco Santos LM, Moura EC, Barradas Barata RC, Serruya SJ, da Motta ML, Silva Elias FT, et al. Fulfillment of the Brazilian agenda of priorities in health research. Health Res Policy Syst 2011; 9:35.

23. Santos LMP, Souza LEPF, Serruya SJ, Guimarães RFN. The role of research in the consolidation of the Unified National Health System (SUS). Cad Saúde Pública 2010; 26:1666-7.

24. Aquino EML. Gênero e saúde: perfil e tendências da produção científica no Brasil. Rev Saúde Pública 2006; 40(Spec no.):121-32.

25. Celeste RK, Bastos JL, Faerstein E. Trends in the investigation of social determinants of health: selected themes and methods. Cad Saúde Pública 2011; 27:183-9.

26. Guimarães R. Pesquisa em saúde no Brasil: contexto e desafios. Rev Saúde Pública 2006; 40(Spec no.):3-10.

27. Barreto ML. A pesquisa em Saúde Coletiva no Brasil. Cad Saúde Pública 2003; 19:354-5.

28. Barreto ML. Crescimento e tendência da produção científica em epidemiologia no Brasil. Rev Saúde Pública 2006; 40(Spec no.):79-85.

29. Tambellini AT, Schütz GE. Contribuição para o debate do Cebes sobre a "Determinação Social da Saúde": repensando processos sociais, determinações e determinantes da saúde. Saúde Debate 2009; 33:371-9.

30. Moloney A. Latin America faces hurdles in health research. Lancet 2009; 374:1053-4. 
31. Guimarães R, Portela Fernandes de Souza LE, Pacheco Santos L, Jacob Serruya S. Não há saúde sem pesquisa: avanços no brasil de 2003 a 2010. Rev Baiana Saúde Pública 2012; 36:55-65.

32. Centro Brasileiro de Estudos de Saúde/Asociación Latinoamericana de Medicina Social. El debate y la acción frente a los determinantes sociales de la salud. Documento de posición conjunto de ALAMES y CEBES. http://www.alames.org/documentos/ alamescebesrio.pdf (accessed on 27/Aug/2013).

33. Funtowicz S, Ravetz J. Post-normal science and extended peer communities in the face of environmental challenges. Hist Ciênc Saúde-Manguinhos 1997; 4:219-30.
34. Breilh J. Epidemiología crítica: ciencia emancipadora e interculturalidad. Buenos Aires: Lugar Editorial; 2003.

35. Porto MF. Ecologia política dos riscos: princípios para integrarmos o local e o global na promoção da saúde e da justiça ambiental. Rio de Janeiro: Editora Fiocruz; 2007.

Submitted on $12 / \mathrm{Sep} / 2013$

Final version resubmitted on 29/Jan/2014

Approved on 27/Mar/2014 